\title{
Work Satisfaction as a Mediation Tool of Organizational Culture
}

\section{Towards Employees' Performance}

\author{
Yustina Olivia Da Silva ${ }^{1}$, Achmad Firdiansjah ${ }^{2}$ and Boge Triatmanto ${ }^{3}$ \\ ${ }^{1}$ Post Graduate Scholar in Management Program, \\ Universityy of Merdeka Malang, Indonesia \\ ${ }^{2,3}$ Faculty Economics and Business, \\ University of Merdeka Malang \\ Indonesia
}

\begin{abstract}
This study aimed (1) to describe the organizational culture, job satisfaction, and employees' performance variables; (2) to analyze the influence of corporate culture variables towards job satisfaction; (3) to investigate the effect of corporate culture and job satisfaction towards employee's performance. The samples employed in this study were 49 people. The analysis technique administered was the model of Structural Equation Modeling. The t-equation model was a combination of factor analysis, regression $t$ and path analysis. The method of the structural equation could be tested to determine the value of direct influence, indirect influence, and the total influence between Exogenous Variables and Endogenous Variables. The organizational culture influenced job satisfaction, which meant that employees' job satisfaction would be obtained if the company had a good organizational culture. Furthermore, organizational culture and job satisfaction affected employees' performance. It could be assumed that the better the organizational culture of the company in supporting its employees in completing the company's work, the more satisfied the employees would be. Moreover, it could improve the employees' performance. Job satisfaction mediated the influence of organizational culture towards employees' performance. Thus, the organizational culture could be inferred having a positive influence in improving employees' performance, if employees felt satisfied with their workplace.
\end{abstract}

Key Words: Organizational Culture, Job Satisfaction, Employees Performance.

\section{INTRODUCTION}

An employee can develop and improve his capabilities if he is supported by a good organizational culture. The organizational culture should contain a collection of basic values, beliefs, and agreements which are being adhered as a basic action demand of the company. It is essential due to the importance of creating organizational culture stability improvement and a feeling of togetherness among employees in achieving organization goals. The condition could be observed in every action and behavior of both leaders and subordinates in cooperating to achieve the company's goals. Robbins (2013) says that a strong organizational culture gives employees a clear understanding of the tasks given by the organization, and has a large influence on the behavior of its members. Employees need to be given a wide-ranged knowledge of organizational culture so that employees are motivated to do their job well.

The previous research conducted by Nurwindagusni (2011) states that there is a significant relationship tendency occurrence between the organizational culture and employees' performance. Therefore, it can be concluded that the strength of the linear relationship between organizational culture and performance is strong. Since employees also always apply the organizational culture well. In addition to organizational culture, job satisfaction also affects employees' performance. It is because of the organizational culture influences employees' performance through job satisfaction. The application of a good organizational culture can encourage employees to work better. When those values and beliefs are brought into daily behavior in work, the employees' performance will also be improved. For example, the work culture of coming to work on time, being responsible for the given work and always being oriented towards the product result can be also considered as ways to improve performance.

The purposes of this study are (1) to describe the following variables: organizational culture, job satisfaction and employees' performance, (2) to analyze the effect of organizational culture variables towards job satisfaction, (3) to analyze the influence of 
organizational culture and job satisfaction towards employees' performance, (4) to analyze the influence of corporate culture towards employees' performance through job satisfaction.

\section{LITERATURE REVIEW}

\subsection{Performance}

The definition of employees' performance according to Dessler (2015: 329) is that the employees' performance is a result of work achieved by people in relation to their position within the organization. According to Wirawan, (2015: 5) employees' performance is an outcome generated by functions and it functions as an indicator of work for a particular period of time. The productivity of an organization is largely determined by the performance of its members. Furthermore, Wibowo (2010: 7) also states that accomplishment originates from the notion of performance. There is a lack of understanding about performance as a working result and working achievements, but actual performance has a broader meaning, not just as a working result but it includes also how the working process continues. In addition, according to Rivai (2010: 67) performance is a real behavior. It is displayed by every person as a working achievement which is produced by employees in accordance with their role in the company. Moreover, Mangkunegara (2007: 67) says that performance is the result of work earned by someone in carrying out tasks that are charged to that person and it is based on his skill levels, experience, seriousness and period. Performance does not entail individual characteristics or traits. It is merely the working ability on an employee which is shown through the processes or working methods and achieving results. Last, Robbins (2013) affirms that performance is a result that should be achieved by an employee in completing his job.

\subsection{Job Satisfaction}

Job satisfaction is basically a subjective matter because each individual has a different level of satisfaction. It is adjusted to the values that exist within each individual. Job satisfaction is the level or degree at which an individual worker has either positive or negative feelings towards his work, such as the physical and social conditions at his working place. According to Robbins, (2013) the satisfaction of cooperation is a positive feeling about the individual work which is resulted from a characteristic of work evaluation. Petrescu and Simmons (2008) define employee job satisfaction as an affectionate response from individuals caused by an assessment of the working role that they currently hold.

A different point of view is uttered by Afandi (2018: 73). He says that job satisfaction is an effective or emotional response to various aspects of employment. A bundle of employees' feelings about the joy or unpleasure things of their work. A general attitude towards work that shows a difference between the number of awards received by workers and the amount of salary they should accept according to their belief.

\subsection{Organization Culture}

Human is a cultured living creature. Each of human action reflects a cultural system that integrates with itself, in terms of thinking, looking at problems, interacting with others, behaving and speaking. In this life, no human is uncultured. It can be either a good culture or bad culture. According to Robbins (2007: 721), organizational culture is a systemic tool of meaning and shared beliefs adopted by the members of the organization. The tool helps to determine most of organization members' ways to interact and act among member and outsiders which distinguishes the organization from other organizations.

\subsection{Hypothesis}

Based on the objectives of the study, the phenomenon and the foundation of the theory that has been previously explained, there are two hypotheses, namely:

H1: Organizational culture has a significant effect on work satisfaction.

H2: Organizational culture and job satisfaction have a significant effect on employees' performance

H3: Organizational culture has a significant effect on employees' performance through job satisfaction.

\section{METHODOLOGY}

This research was explanatory research. It was an explanatory study that highlighted the relationship between research variables and tests hypotheses that had been formulated (Singarimbun and Effendi, 2005: 5). Organizational culture was a point of view and values that were believed by all members of an organization. It acted as behavioral guidelines, and a marker that made one organization differed from other organizations. The indicators used in this research, namely: Results-oriented, Individualoriented, Team-oriented, Aggressiveness, and Stability.

Job Satisfaction was the feeling of pleasure for individuals in carrying out work activities and it could be measured by indicators: Meeting needs, Differences, Achieving values, Justice. The performance was a work outcome that could be achieved by someone 
or a group of people in carrying out their duties according to the responsibilities given. Furthermore, it could be measured by the following indicators: Quality, Quantity, Resilience to work, Attitude.

The population in this study were the employees at PT. Krebet Sugar Factory, Bululawang Malang. By taking into account the small number of populations, the members of the research population were all employed so that this research could be counted as a study of population or census.

\section{Techniques for Data Analysis}

Descriptive analysis was intended to analyze data to reveal the main objectives. This was how the data could be described further in terms of how it was summarized either numerically or graphically to get a glimpse of the data. It was meant that the data would be easier to be read and it was more meaningful. In this study, the descriptive analysis techniques were used to describe organizational culture, job satisfaction, and employees' performance. Descriptive statistical data was collected by finding the average arithmetic (mean) and the standard deviation of the variance.

The Structural Equation Modeling which was better known as SEM was administered. This structure was a combination of factor analysis, regression, and path analysis. In the structural equation method, we could conduct a test to determine the direct effect, indirect effect, and the total effect between endogenous and exogenous variables.

\section{RESEARCH RESULT}

\subsection{The Influence of Organizational Culture towards Employees' performance through Job Satisfaction}

The hypothesis test model was carried out by path analysis, namely by using simple regression and multiple regression then filtered it based on statistical and significance tests. This statistical test could be performed using the beta coefficient/ standardized coefficient (standard $\beta$ ). If the $\beta$ value was significant, then the path coefficient was significant. The path coefficients that were not significant, were discarded. Significance testing could be administered by comparing the significance of the pathway. If the significance value of the path coefficient was less than 0.05 , then the 1 coefficient was considered significant. Conversely, if the significant coefficient value was greater than 1.005, then it was considered to be insignificant. To see the influence of organizational culture towards the employees' performance through job satisfaction is presented in Table 1 below.

Table 1. The Summary of Direct Influence Analysis, Indirect Influence Analysis, and Total Path Analysis

\begin{tabular}{|c|c|c|c|c|c|c|c|}
\hline Variables & & & $\begin{array}{c}\text { Direct } \\
\text { Influence }\end{array}$ & T Values & P Values & $\begin{array}{c}\text { Indirect } \\
\text { Influence }\end{array}$ & $\begin{array}{c}\text { Total } \\
\text { Influence }\end{array}$ \\
\hline Organizational Culture & $\rightarrow$ & Satisfaction & 0,819 & 9,770 & 0,000 & - \\
\hline Organizational Culture & $\rightarrow$ & $\begin{array}{c}\text { Employees' } \\
\text { performance }\end{array}$ & 0,462 & 3,171 & 0,003 & - \\
\hline Work Satisfaction & $\rightarrow$ & $\begin{array}{c}\text { Employee's } \\
\text { Performance }\end{array}$ & 0,402 & 2,760 & 0,008 & - \\
\hline $\begin{array}{l}\text { Organizational Culture } \\
\rightarrow \text { Work Satisfaction }\end{array}$ & $\rightarrow$ & $\begin{array}{c}\text { Employee's } \\
\text { Performance }\end{array}$ & 0,462 & - & - & $\begin{array}{c}0,819 \times 0,402= \\
0,329\end{array}$ \\
\hline
\end{tabular}

* Significant at $\alpha 5 \%$.

Based on Table 1, it appeared that the total effect of organizational culture variables on employees' performance $(1,133)$ was greater than the direct influence $(0,462)$. These results indicated that the status of work satisfaction was an intervening variable in the influence of organizational culture towards employees' performance because the total value was greater than the direct influence.

\subsection{Hypothesis testing}

Based on Table 1, the beta value of the organizational culture was 0.819 and the value of $\mathrm{t} 1$ was 9.770 and the value of $\mathrm{p}$ was 0.000 less than $\mathrm{p}=1.05(\alpha=5 \%)$, which meant that organizational culture had a significant effect towards satisfaction. Thus, the first hypothesis which stated that organizational culture had a significant effect on work satisfaction was statistically tested.

Based on Table 1, the beta value of the organizational culture was 0.462 and the value of $t 1$ was 3.171 and the $p$-value was 0.003 which was smaller than $\mathrm{p}=10.05(\alpha=5 \%)$. It meant that the organizational culture had a significant effect on employees' performance. The job satisfaction beta coefficient was 0.402 and the value of $t 1$ was 2.7601 . Next, the p-value of 0.008 was smaller than $p=10.05(\alpha=5 \%)$, which meant that job satisfaction had a significant effect on employees' performance. Thus, the second hypothesis which stated that organizational culture and job satisfaction had a significant effect on employees' performance was statistically tested.

Based on Table 1 the results of the analysis showed that status satisfaction as an intervening variable could mediate organizational culture variables towards employees' performance because the total influence value was greater $(0.801)$ than direct influence 
(0.462). Therefore, it could be stated that the third hypothesis was statistically tested since the organizational culture influenced significantly towards employees' performance through job satisfaction.

Based on the description of hypothesis testing, the path model in path analysis is presented in Figure 1 below.

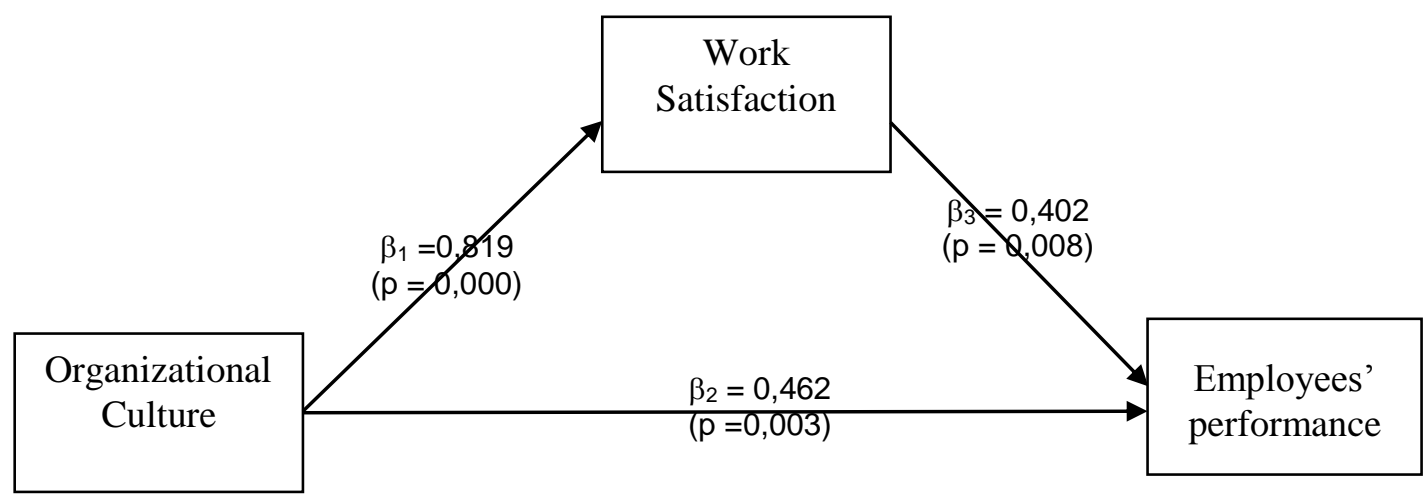

Picture 1 Path Analysis Results

\section{RESULT DISCUSSION}

Organizational culture was shaped by the followings: results orientation, people orientation, team orientation, aggressiveness, and stability. The main thing that supported organizational culture was aggressiveness, namely in carrying out the work, sometimes employees loved to pass/ exchange information with colleagues. Organizational culture was a chain of binding in the process of equality of perception or direction of members towards a problem so that it would eventually become a strength in achieving organization goals.

Job satisfaction was formed by meeting needs, differences, achievement of values, and justice. The main thing that built job satisfaction was justice, namely from the way employers dealt with the employees' problems that should be adhered to. This showed that one of the important targets at the firm was the creation of employee job satisfaction. It was expected that job satisfaction would be able to help the firm to achieve its goals better and more accurate.

The employees' performance was shaped by quality, quantity, resilience to work and attitude. The main thing that could improve employees' performance was the attitude that respondents owned the ability to make good decisions. The performance was an accomplishment achieved by employees in carrying out his tasks or jobs which was in accordance with the standard criteria specified in the work.

Organizational culture influenced job satisfaction, which meant that employee job satisfaction was obtained if the company had a good organizational culture. The results of this study were consistent with Arifin Noor (2018) and Marzuki (2018) finding which stated that organizational culture influenced job satisfaction. Organizational culture could help to create a sense of belonging towards the organization; creating the identity of members of the organization; creating tight attachment between organizations and employees involved in it; helping to create organizational stability as a social system, and finding patterns of behavioral guidance as a result of habitual norms formed in everyday life. As previously stated by Robbins (2007: 721), the organizational culture was a systemic tool of meaning and shared beliefs adopted by organizational members who determined most of their ways to interact and act between group members and outsiders. Therefore, it would distinguish the organization from other organizations. Thus, organizational culture had a strong influence on employee's job satisfaction.

Organizational culture influenced employees' performance, which meant that the better organizational culture, the better the employee's performance would be. The results of this study were in line with Dimyati (2018), Brahmasari and Suprayitno (2018) which stated that organizational culture influenced employees' performance. Organizational culture was the spirit of the organization because there were philosophies, visions and organizational missions that would become the important strengths for the organization to compete with others. Organizational culture was an ability to establish appropriate behavior which was expected by the organization itself in accordance with the employees' performance. Organizational culture shaped staff behavior by encouraging the mixing of core values and desirable behavior so that it allowed organizations to work more efficiently and effectively to improve consistency, resolve conflict, and facilitate coordination and control.

Job satisfaction influenced employees' performance, which meant that the more satisfied the employees working in the company, the higher will be the employee's performance improvement. The results of this study were in line with Soedjono (2017) and Tobing (2017) which stated that job satisfaction affected employees' performance. The tendency to improve employees' performance in the company could not be achieved without the presence of employees' job satisfaction. Job satisfaction was a form of pleasure towards what had been done, but the satisfaction of work was subjective. The satisfaction between individuals tends to be different also, because each individual had his own satisfaction criteria in measuring his level of satisfaction, nevertheless employees' satisfaction in work could be seen from how the employee performed his job. This was 
consistent with Robbins' opinion (2013) that the satisfaction of cooperation was a positive feeling about the work of the individual produced from the evaluation of the characteristics of his work. The work satisfaction was enjoyed at work, outside work, and in combination between at work and outside of work. Satisfied employees will encourage themselves to perform better. Employees who feel satisfied in work would always arrive on time, meaning that the employee respected his work and was responsible for the tasks they must do. They felt glad to carry out the work. They did not complain about the tasks and work. It could be said that they could always accept new and difficult jobs with an open mind. They had a harmonious relationship with other employees and supervisors.

Job satisfaction mediated the influence of organizational culture towards employees' performance, which meant that organizational culture could improve employees' performance if employees felt satisfied with their work. Employees' assessment towards his work and his condition was closely related to employee job satisfaction. This was caused by a positive assessment that could improve employees' job satisfaction, while the negative assessment could lead to employees' job dissatisfaction. Organizational culture played a role in influencing employees' behavior. This could be reflected within the opportunity to innovate and create, the opportunity to think, good relationships, and others so that the organizational culture could function in creating job satisfaction and making an optimal performance impact as an effort to achieve organization goals.

\section{CONCLUSION}

The descriptive results show that organizational culture is shaped by orientation results, people orientation, team orientation, aggressiveness, and stability. The main thing that supports organizational culture is aggressiveness, that is, from carrying out work, employees like to share information with colleagues. Job satisfaction is formed by meeting needs, differences, achievement of values, and justice. The main thing that builds job satisfaction is justice, namely from the way employers deal with the problems of employees that could be seen as an example. Employees' performance is shaped by quality, quantity, resilience to work and attitude. The main thing that can improve employees' performance is making good decisions ability attitude.

Organizational culture influences job satisfaction, which means that employees' job satisfaction is obtained if the company has a good organizational culture. Organizational culture and job satisfaction affect employees' performance. It means that the better the organizational culture of the company by supporting its employees, the more satisfied will be the employees in completing their work so that it would lead to employees' performance improvement. Job satisfaction mediates the influence of organizational culture on employees' performance, which means that organizational culture can improve employees' performance if employees feel satisfied with their work.

\section{SUGGESTION}

It is better for employees to maintain their work quality. In order to achieve employees' job satisfaction, the company should pay attention more towards the appreciation activities for its employees. It is suggested for every employee to constantly improve their knowledge and follow technological developments through training. For the next researcher, is expected to be able to conduct research development by using other free variables such as organizational commitment, leadership style, OCB, and competence, so that the research can give more influence towards employees' performance.

\section{REFERENCES}

1. Afandi P, 2018, Manajemen Sumber Daya Manusia : Teori, Konsep dan Indikator. Nusa Media, Yogyakarta.

2. Arifin Noor, Zainul, 2018, Pengaruh Budaya Organisasi, Komitmen Organisasi dan Motivasi Kerja Terhadap Kepuasan Kerja dan Kinerja Karyawan Pada PT. Indofood Sukses Makmur Tbk di Kalimantan Selatan, Jurnal Ekonomi dan keuangan Vol. 1 No. 4 Januari 2018, hal 71-85.

3. Brahmasari, Ida, Ayu dan Agus Suprayitno, 2018, "Pengaruh Motivasi Kerja, Kepemimpinan dan Budaya Organisasi Terhadap Kepuasan Kerja Karyawan Serta Dampaknya Pada Kinerja Perusahaan” (Studi Kasus pada PT. Pei Hai Internasional Wiratama Indonesia). Jurnal Manajemen dan Kewirausahaan Vol. 10 No. 2 September 2018, hal 124-135.

4. Dessler, G. 2015, Human Resource Management, edisi 14. Penerbit Salemba Empat, Jakarta.

5. Dimyanti, Muhamad Reza, 2018, Analisis Pengaruh Budaya Organisasi dan Kepuasan Kerja Terhadap Kinerja Pegawai dan Komitmen Organisasi sebagai Variabel Pemediasi Pada Dinas Perhubungan, Komunikasi dan Informasi di Pekalongan. Jurnal Ekonomi Universitas Diponogoro Semarang.

6. Dino,Soedjono, 2017, "Pengaruh Budaya Organisasi Terhadap Kinerja Organisasi dan Kepuasan Karyawan Pada Terminal Penumpang Umum di Surabaya, Tesis Magister Manajemen Pascasarjana Universitas Petra, Surabaya.

7. Hasan Marzuki, Teman, 2018 "Pengaruh Budaya Keselamatan Kerja, Kepemimpinan dan Motivasi terhadap Kepuasan Kerja dan Kinerja Karyawan pada Perusahaan Minyak dan Gas di Propinsi Kalimantan Timur", Jurnal Bisnis dan Manajemen Vol. 12 No. 1 Januari 2018, hal 51-65.

8. Mangkunegara, Anwar Prabu, 2007, Evaluasi Kinerja Sumber Daya Manusia, Cetakan Ketiga, PT. Refika Aditama, Bandung. 
International Journal of Advances in Scientific Research and Engineering (ijasre), Vol 5 (3), March-2019

9. Petrescu, Simmons, 2008, Human Resources Management Practices and Workers Job Satisfaction. UK: Emerald Group Publishing Limited.

10. Rivai, Veithzal. 2010. Manajemen Sumber Daya Manusia Untuk Perusahaan Dari Teori ke Praktik. PT. RajaGrafindo Persada, Jakarta.

11. Robbins, Stephen P dan Timothy A. Judge, 2013, Organizational Behavior, 15th ed. Pearson Prentice Hall, New Jersey.

12. Robbins, 2007, Perilaku Organisasi: Konsep Kontravensi dan Aplikasi, Edisi ke-9, Jilid I, PT. Prenhallindo, Jakarta.

13. Tobing Diana, 2017, Pengaruh Komitmen Organisasi dan Kepuasaan Kerja terhadap Kinerja Karyawan pada PT. Perkebunan Nusantara III di Sumatera Utara, Jurnal Manajemen dan Kewirausahaan Vol.11 No. 1 Maret 2017, hal 3137.

14. Wibowo, 2010, Manajemen Kinerja, PT. RajaGrafindo Persada, Jakarta.

15. Wirawan, 2015, Evaluasi Kinerja Sumber Daya Manusia, Teori Aplikasi dan Penelitian, Penerbit Salemba Empat, Jakarta. 